\title{
Erratum to: PLC $\zeta$ disruption with complete fertilization failure in normozoospermia
}

\author{
Mercè Durban $^{1}$ - Montserrat Barragán ${ }^{1}$ - Marta Colodron ${ }^{1}$. \\ Minerva Ferrer-Buitrago ${ }^{2}$ - Petra De Sutter ${ }^{2}$ - Björn Heindryckx ${ }^{2}$. \\ Valérie Vernaeve $^{1} \cdot$ Rita Vassena $^{1}$
}

Published online: 1 July 2015

(C) Springer Science+Business Media New York 2015

Erratum to: J Assist Reprod Genet (2015)

DOI 10.1007/s10815-015-0496-0

The original version of this article unfortunately contained a mistake. The family name of Björn Heindryckx was misspelled, omitting letter " $\mathrm{x}$ ". The update is provided here as well.

The online version of the original article can be found at http://dx.doi.org/ 10.1007/s10815-015-0496-0.

$\triangle$ Rita Vassena

rvassena@eugin.es

1 Clínica EUGIN, Travessera de les Corts 322, 08029 Barcelona, Spain

2 Ghent Fertility and Stem Cell Team (GFaST), Department for Reproductive Medicine, Ghent University Hospital,

9000 Ghent, Belgium 